\title{
Molecular characterization of lactic acid bacteria producing edible biofilm isolated from kimchi
}

\author{
FADILLA SAPALINA ${ }^{1}$, ENDAH RETNANINGRUM ${ }^{2, \varphi}$ \\ ${ }^{1}$ Graduate Program of Biology, Faculty of Biology, Universitas Gadjah Mada. Jl. Teknika Selatan Sekip Utara, Sleman 55281, Yogyakarta, Indonesia \\ ${ }^{2}$ Microbiology Laboratory, Faculty of Biology, Universitas Gadjah Mada. Jl. Teknika Selatan Sekip Utara, Sleman 55281, Yogyakarta, Indonesia. \\ Tel/fax.+62-274-580839, ’email: endahr@ugm.ac.id
}

Manuscript received: 1 December 2019. Revision accepted: 8 February 2020.

\begin{abstract}
Sapalina F, Retnaningrum E. 2020. Molecular characterization of lactic acid bacteria producing edible biofilm isolated from kimchi. Biodiversitas 21: 962-968. Biofilm is a community of microorganisms that interrelated and covered by an extracellular polymer matrix. This biofilm can be produced by lactic acid bacteria (LAB) which is edible for human and animals. Therefore, it possible to be applied in the food and health industry. One source of LAB is kimchi, a fermented food from Korea having good benefits for health. This research aimed to obtain LAB from kimchi which produces edible biofilms and to identify their isolates based on the 16S rRNA gene. Isolation of lactic acid bacteria from kimchi was conducted using MRS agar medium containing $1 \% \mathrm{CaCO}_{3}$. The isolates of $\mathrm{KA}_{2}$, $\mathrm{KA} 5, \mathrm{~KB} 1$, and $\mathrm{KC} 4$ were obtained from kimchi and could produce biofilms with the highest biofilm formation at 48 hours incubation time. Their biofilm products were proven to be attached to the surface of zeolites. Analysis of 16S rDNA sequence revealed those four isolates were identified as Lactobacillus brevis.
\end{abstract}

Keywords: Extracellular polymer matrix, Lactobacillus brevis, 16S rRNA gene, zeolite

\section{INTRODUCTION}

Lactic acid bacteria (LAB) have the ability to form biofilms on various surfaces widely used in food industries (Gomez et al. 2016). Biofilm produced by LAB is an edible biofilm source because of safe for human consumption, therefore it is called edible biofilm. Edible biofilms are formed by microbes and they are covered by a matrix. According to Guerrieri et al. (2009), LAB biofilms can be developed as new technologies in the field of food packaging. These food packaging systems are carried out through active packaging planning by adding LAB producing biofilms to food. Nowadays, bacterial biofilms are being widely investigated with a view to developing environmentally friendly packaging due to several considerations. These biofilms were effective barriers to water vapor, regenerated mechanical vigor and enhanced microbiological and oxidative stability packaged food by enhancing its antimicrobial and antioxidant capabilities (Valdes et al. 2017).

Biofilm was defined as complex bacterial communities within a matrix of exopolysaccharides and adheres to a surface Biofilm was defined as complex communities of bacteria within an exopolysaccharide matrix and adheres to a surface (Khatoon et al. 2018). The microorganisms form this matrix in the form of extracellular polymer or extracellular polymeric substances (EPS). The chemical composition of that matrix consists of proteins that include enzymes, DNA, RNA, polysaccharides, and water. Whereas, water is the major part of that biofilm (up to 97\%) and responsible for nutrient flow inside the biofilm matrix (Nazir et al. 2019). Various studies have shown that bacterial biofilms increase cell resistance which protects their cells from stressor conditions, such as extreme $\mathrm{pH}$, salinity, drought and heavy metal (Bove et al. 2012; Retnaningrum and Wilopo 2016; Pang and Yuk 2019; Chang et al. 2020). The biofilms were also reported could reduce the pathogenic microorganisms. Researchers reported several LAB strains, such as Weissela viridescens 113 bac-, L. lactis 69 bac+, L. lactis 94 bac+, L. casei 40 bac-, L. helveticus 352 bac-, L. casei $\mathrm{Y} 1$, L. plantarum $\mathrm{KF}$ and L. brevis BBE-Y52 could produce biofilms with antibacterial pathogen (Gomez et al. 2016; Kumar et al. 2017; Fang et al. 2018).

Kimchi is a familiar Korean fermented vegetable food. Kimchi's marketing has been increased worldwide due to its taste and health benefits, and has now become one of the world's most popular food products. In addition, these fermentation products were reported by some researchers as being a source of lactic acid bacteria, including the species of Leuconostoc sp, Lactobacillus sp, Weissella sp and Lactococcus sp (Jang et al. 2015). Based on reports by Lee et al. (2016), they have achievement identified at species level using 16S rRNA marker gene. This marker gene was used for that identification because of some of those properties, such as: (1). It is ubiquitous, distributed to all archaea and bacterial lineages, (2). The rate of evolution is relatively slow and laterally gene transfer is not easy, (3). The 16S rRNA gene has conserved and varied regions. Therefore, the 16S rRNA gene is very accurate and stable to be used as a phylogenetic marker and to find out the genetic relationship between organisms (Kim and Chun 2014). Recent researches have reported the probiotic properties of LAB from kimchi as anti-bacterial pathogen, 
anti-virus and anti-diabetic (Son et al. 2017; Kim et al. 2019; Hossain et al. 2020; Seo et al. 2020). However, the LAB potential of kimchi as an edible biofilm producer has never been reported. Therefore this research was conducted to isolate LAB from kimchi which produces edible biofilm and also to molecularly identify their LAB based on the $16 \mathrm{~S}$ rRNA gene.

\section{MATERIALS AND METHODS}

\section{Isolation of lactic acid bacteria}

The samples of kimchi were collected from local market in Yogyakarta, Indonesia. Aseptically, $5 \mathrm{~g}$ of the sample was added into $45 \mathrm{~mL}$ of sterile $0.85 \%$ (w/v) $\mathrm{NaCl}$ solution and mixed thoroughly. Furthermore, a dilution series of $10^{-1}$ to $10^{-8}$ was made. Three of the appropriate dilutions in the series $\left(10^{-6}-10^{-8}\right)$ were taken as $1 \mathrm{~mL}$ in each (three replications) using micropipette and inoculated on a selective medium of MRS agar (Oxoid) with $1 \%$ $\mathrm{CaCO}_{3}$ (w/v). Then, it was incubated at $37^{\circ} \mathrm{C}$ for 48 hours. Colonies that form halo zones were recognized as lactic acid bacteria colonies. Furthermore, colonies with different characters (type, size, and shape) were observed and purified by the streak plate method on the MRS agar medium to obtain a single colony. Isolates with Grampositive characters, negative endospores, non-motile and negative catalase were used for further tests.

\section{Selection of LAB isolates producing biofilm}

The selection of LAB isolates producing biofilm was carried out by microscope qualitative observation using the technique described in Gomez et al. (2016), with certain modifications. One loop of bacterial isolate was inoculated into $9 \mathrm{ml}$ of MRS broth medium (Himedia) and incubated at $37^{\circ} \mathrm{C}$ for 24 hours. The culture was taken at the end of the incubation period and adjusted with sterile MRS broth medium to achieve a cell suspension of $0.25 \pm 0.05$ OD (optical density) which determined by a spectrophotometer $\lambda 600 \mathrm{~nm}$. Such bacterial cell numbers corresponded to an inoculum of $10^{7}-10^{8} \mathrm{CFU} / \mathrm{mL}$. A $3 \mathrm{ml}$ of that bacterial culture was inoculated into a $250 \mathrm{~mL}$ flask containing 100 $\mathrm{mL}$ MRS broth with added $10 \mathrm{~g}$ zeolite in the diameter range between 0.4-0.6 cm (Retnaningrum and Wilopo 2017). The culture was then incubated at $37^{\circ} \mathrm{C}$ for 96 hours. During the period of incubation, culture samples were taken and further observed for biofilm formation by investigating through a microscope.

\section{Evaluation of biofilm production at different incubation times}

Biofilm production of $\mathrm{LAB}$ isolates was observed at interval incubation times of 24, 48, 72 and 96 hours by measuring their turbidity using spectrophotometer. Enumeration of bacterial cell numbers in biofilms conducted through the total plate count (TPC) method in nutrient agar medium (Himedia). The TPC method conducted with serial dilutions $\left(10^{-6}-10^{-8}\right)$ were taken as 1 $\mathrm{mL}$ in each (three replications) using micropipette and inoculated on a selective medium of nutrient agar. Then incubated at $37^{\circ} \mathrm{C}$ for $48 \mathrm{hr}$ and counted their colonies number.

\section{Identification of LAB isolates producing biofilm}

For molecular identification of LAB isolates from kimchi using the 16S rRNA gene, pure isolates were prepared and purified with the streak plate method. Then a separate colony was inoculated on $50 \mathrm{~mL}$ nutrient broth medium (Himedia) and incubated for 48 hours. A quickDNA $^{\mathrm{TM}}$ fungal/bacterial miniprep kit (Zymo Research, USA) was used to isolate the bacterial DNA of that culture. Amplification of the16S rRNA was using 27F (5'AGAGTTTGATCCTGGCTCAG-3') and 1492R (5'GGTTACCTTGTTACGACTT-3') (Hossain et al. 2020) in a thermocycler (Bio-Rad, USA). The PCR condition contained pre-denaturation at $95^{\circ} \mathrm{C}$ for $30 \mathrm{~min}$, followed by 30 cycles consisting of denaturation at $95^{\circ} \mathrm{C}$ for $30 \mathrm{sec}$, annealing at $57^{\circ} \mathrm{C}$ for $1 \mathrm{~min}$, extension at $72^{\circ} \mathrm{C}$ for $1 \mathrm{~min}$, and final extension $72^{\circ} \mathrm{C}$ for $10 \mathrm{~min}$. The PCR products were then purified and sequenced using Sanger method. The sequences results were then edited by using GeneStudio. Sequence similarities were matched with DNA sequence databases (GenBank) through the BLAST program (BLASTn) at the National Biotechnology Information Center (NCBI). Phylogenetic tree analysis using Molecular Evolutionary Genetics Analysis X (MEGA version $\mathrm{X}$ ).

\section{RESULTS AND DISCUSSION}

\section{The LAB isolates from kimchi}

Seventeen bacteria (KA2, KA3, KA4, KA5, KA6, KB1, KB4, KB5, KB6, KB8, KB9, KB10, KC1, KC2, KC4, $\mathrm{KC6}$, and $\mathrm{KC} 7$ isolates) with clear zone around their colonies have been successfully isolated from kimchi samples in MRS agar supplemented with $1 \% \mathrm{CaCO}_{3}$. In addition, their characters were Gram-positive bacteria, rod shape, negative catalase, non-motile, and negative endospore that matched the LAB key characters in Bergey's Manual of Determinative (Brenner et al. 2005). Similar LAB characters were also reported by Nurhikmayani et al. (2019).

\section{The selected LAB isolates producing biofilm}

For selection of those LAB that produces biofilm, they were observed under microscope after 48 hours incubation in MRS broth with zeolite addition as an abiotic substrate for their cell attachments. In this procedure, the selections were conducted based on their high adherent bacterial cells population in the zeolite as shown in Figure 1. The reasons for using zeolite as an abiotic substrate attachment are as follows: (i) Zeolite categorized as GRAS (Generally Regarded as Safe) which is safe for humans and animals, (ii) It has a microstructure and it can produce a high ion binding capacity (Fan et al. 2018).

Those observation results indicated that biofilm was composed of bacterial cells that were attached to each other for intercommunication. According to Piard and Briandet (2016), the regulation of biofilm formation by LAB is 
carried out through a process called QS (Quorum Sensing). The bacteria use quorum sensing communication circuits to control physiological activity including the formation of biofilms. Quorum sensing of LAB delivered chemical signal molecules which were called AIP (Auto-Inducing Peptides) and AI-2 (Autoinducer-2). This allows bacteria to communicate with other bacterial cells. Hence, in microscope showed bacterial community bound to each other. The bacteria can know the condition of their environment and adapt to the regulation of specific genes because of quorum sensing.

\section{Biofilm production of LAB isolates during a period of incubation times}

To confirm that LAB isolated from kimchi could produce biofilm, each of isolate was cultured and incubated for 96 hours. During the incubation period, both biofilm production and LAB cell number were measured using the spectrophotometric method and total plate count as shown in Figure 2. Both of biofilm production and cell numbers of the four LAB isolates increased in parallel. These increases started at 24 hours, then reached their maximum at 48 hours. Isolates of $\mathrm{KA} 2, \mathrm{KA} 5, \mathrm{~KB} 1$, and $\mathrm{KC} 4$ produced biofilms, each measured absorbancy values of $1.55,1.57,1.62$ and 1.49. However, at 72 hours of incubation, biofilm production started to decrease and continued up to 96 hours.

According to Kumar et al. (2017), the absorbance value of bacteria culture was greater than 0.1 indicated the presence of biofilms produced by its bacteria culture.
Therefore, those four isolates could be categorized as biofilms producers. In addition, the bacterial cell numbers were shown equivalent to biofilm production. The highest cell number was also seen at 48 hours incubation time. Whereas the total cell numbers of those four isolates were $5.63 \times 10^{7}, 5.72 \times 10^{7}, 5.89 \times 10^{7}$ and $5.39 \times 10^{7} \mathrm{CFU} / \mathrm{mL}$. Biofilm production by each of LAB isolate was different depending on the type of that isolate because of the different abilities in producing biofilms. The KB1 isolate showed the highest biofilm production ability compared to $\mathrm{KA} 2$, KA5, and KC4 isolates.

The fluctuation of biofilm production was inseparable with the influence of isolate ability to form biofilms. In addition, environmental factors also affected biofilm formation. Piard and Briandet (2016) reported that biofilms production by bacteria could be affected by exogenous environmental factors, such as the physicochemical properties of biotic or abiotic surfaces, nutrition for bacteria, changes in oxygen and $\mathrm{pH}$, the presence of biocide or antibiotics. Meanwhile, nutrition for bacteria in the medium has to be maintained. Nutrition in the medium becomes reduced as the numbers of biofilm-forming bacteria increased. It indicated a phenomenon of nutrition competition. Then, the bacteria were unable to survive, they would die and bacteria cell numbers decreased. Similarly, results were reported by Chen et al. (2017), they investigated the optimum biofilm production of $L$. plantarum and L. citreum which depend on several conditions such as low $\mathrm{pH}$, low temperature and high osmolality.

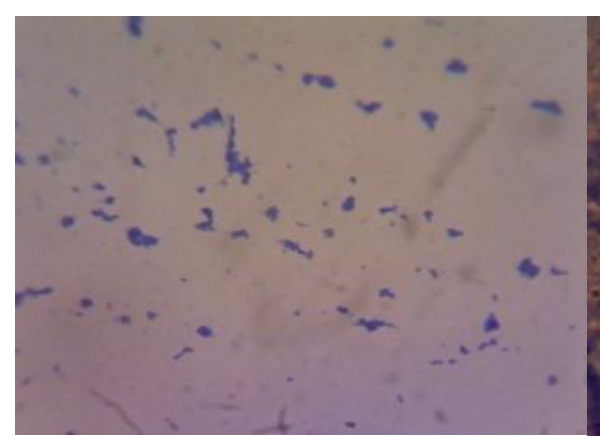

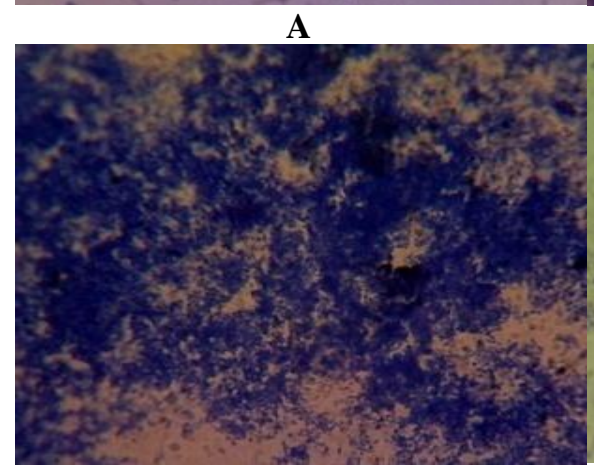

D

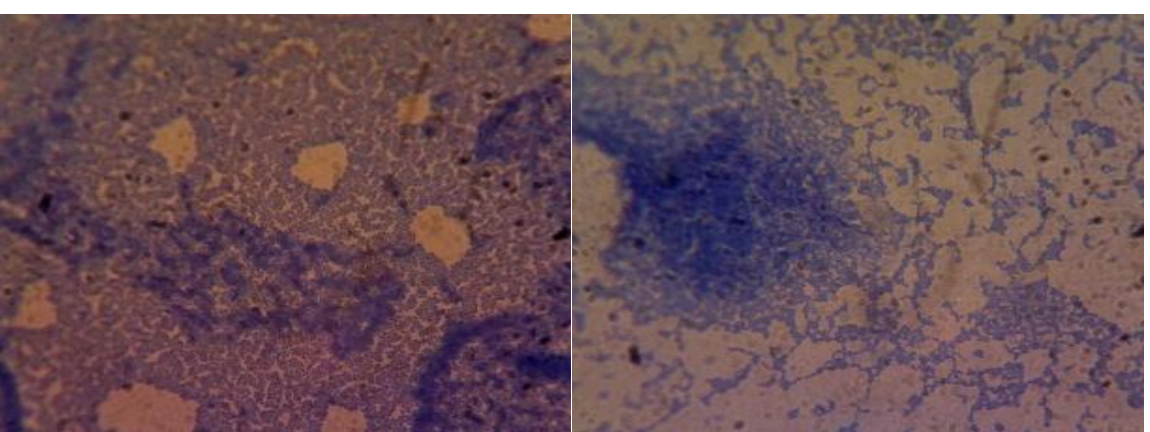

B

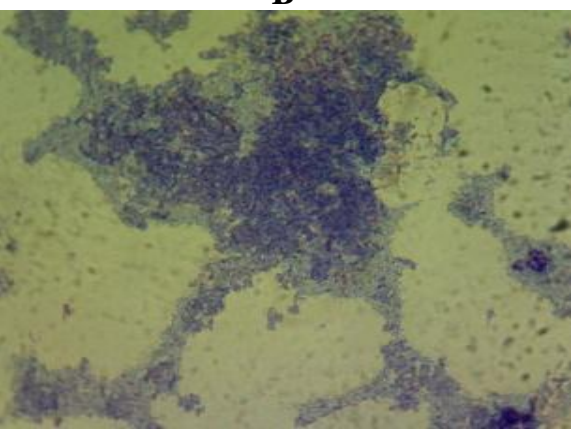

$\mathbf{E}$

Figure 1. Microscopic observations of LAB biofilms at 1000x magnification, (A) control without biofilm of LAB cells, (B) KA2, (C) $\mathrm{KA}$, (D) KB1 and (E) KC4 isolate 


\section{Molecular characters of LAB isolates producing biofilm}

The four LAB isolates producing biofilm were characterized molecularly based on 16S rRNA gene. The results of PCR amplification of 16S rRNA gene from those isolates produced length fragments around 1500 bp DNA (Figure 3). These results corresponded with Johnson et al. (2019) who investigated the similar sequences result of the 16S rRNA gene with length fragments of $1500 \mathrm{bp}$. Therefore, the 16S rRNA sequences of those samples were edited using GeneStudio software. Consensus sequences similarities results were matched with DNA sequence databases GenBank through the BLASTn program in NCBI. Those BLAST results showed that all isolates (KA2, $\mathrm{KA} 5, \mathrm{~KB} 1$, and KC4 isolates) had similarity $>99 \%$ with Lactobacillus brevis ATCC 14869 (Table 1). As explained by Schlaberg et al. (2012), the percentage similarity of isolates was categorized in the level of the same species, genus, family, and order if the values were $\geq 99 \%, 97 \%$ to $<99 \%, 95 \%$ to $<97 \%$ and $<95 \%$, respectively. Furthermore, the alignment of 16S rRNA sequences and reconstruction of phylogenetic tree were further analyzed with MEGA X. All positions which contain gaps and missing data have been removed.

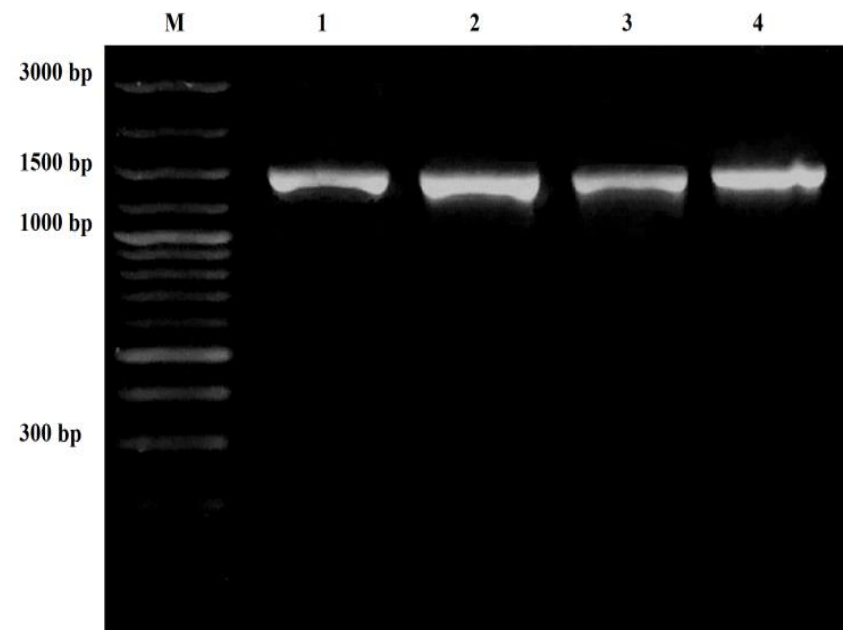

Figure 3. Electropherogram of $16 \mathrm{~S}$ rRNA gene of $\mathrm{LAB}$ isolates with pairs primer of 27F and 1429R (M: Marker $100 \mathrm{bp}, 1$ : KA2, 2: KA5, 3: KB1 and 4: KC4 isolate)

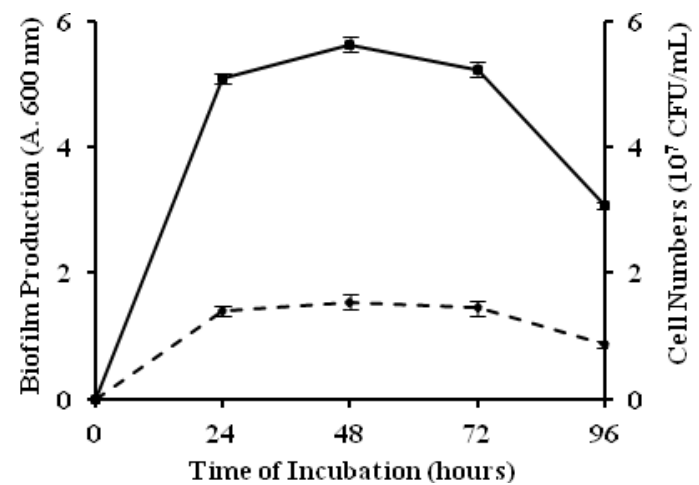

A

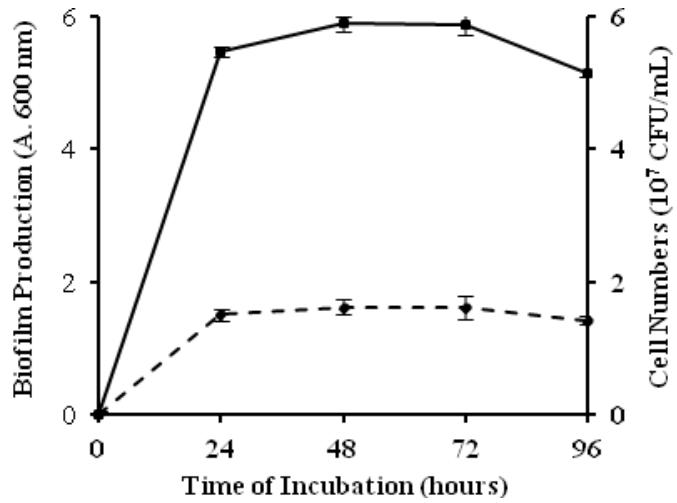

C

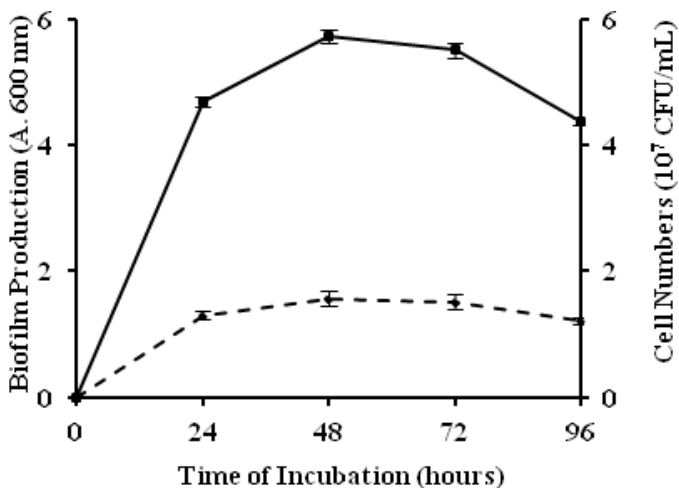

B

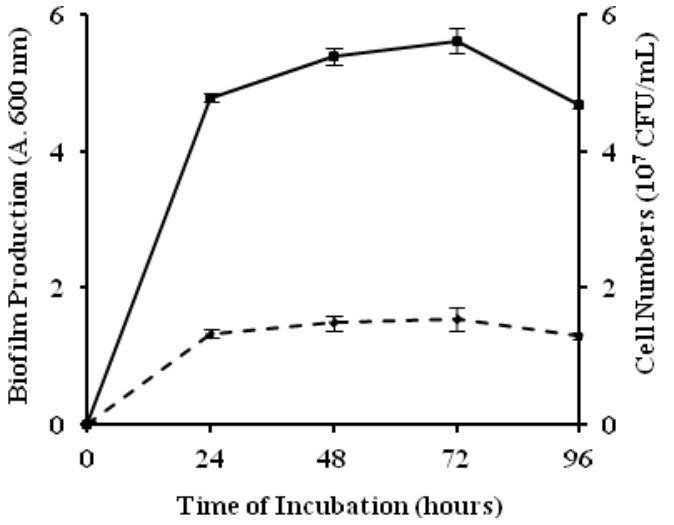

D

Figure 2. Biofilm production by LAB isolates from kimchi during a period of incubation times, (A). KA2 isolate, (B) KA5 isolate, (C). $\mathrm{KB} 1$ isolate, (D). KC4 isolate 
Table 1. The BLAST results of LAB isolates from kimchi

\begin{tabular}{|c|c|c|c|c|c|c|}
\hline Isolate & Species of LAB Homolog & $\begin{array}{l}\text { Query } \\
\text { cover }\end{array}$ & Identity & $\begin{array}{l}\text { Accession } \\
\text { number }\end{array}$ & Isolate sources & References \\
\hline \multirow[t]{5}{*}{$\overline{\text { KA2 }}$} & Lactobacillus brevis ATCC 14869 & $99 \%$ & $99.05 \%$ & NR_044704.2 & Culture collection & $\begin{array}{l}\text { Woese et al. (2011) } \\
\text { (Unpublished) }\end{array}$ \\
\hline & $\begin{array}{l}\text { Lactobacillus brevis ATCC } 14869= \\
\text { DSM } 20054\end{array}$ & $97 \%$ & $99.72 \%$ & NR_116238.1 & Dairy product & Coton et al. (2008) \\
\hline & Lactobacillus hammesii TMW 1.1236 & $99 \%$ & $97.82 \%$ & NR_042243.1 & France sourdough & Valcheva et al. (2005) \\
\hline & Lactobacillus senmaizukei DSM 21775 & $99 \%$ & $97.68 \%$ & NR_114251.1 & Culture collection & $\begin{array}{l}\text { Nakagawa et al. (2014) } \\
\text { (Unpublished) }\end{array}$ \\
\hline & $\begin{array}{l}\text { Lactobacillus cerevisiae TUM BP } \\
140423000-2250\end{array}$ & $98 \%$ & $97.60 \%$ & NR_158030.1 & Spoilage brewery & Koob et al. (2017) \\
\hline \multirow[t]{5}{*}{ KA5 } & Lactobacillus brevis ATCC 14869 & $99 \%$ & $99.52 \%$ & NR_044704.2 & Culture collection & $\begin{array}{l}\text { Woese et al. (2011) } \\
\text { (Unpublished) }\end{array}$ \\
\hline & $\begin{array}{l}\text { Lactobacillus brevis ATCC } 14869= \\
\text { DSM } 20054\end{array}$ & $97 \%$ & $100 \%$ & NR_116238.1 & Dairy product & Coton et al. (2008) \\
\hline & Lactobacillus hammesii TMW 1.1236 & $99 \%$ & $98.29 \%$ & NR_042243.1 & France sourdough & Valcheva et al. (2005) \\
\hline & Lactobacillus senmaizukei DSM 21775 & $99 \%$ & $98.15 \%$ & NR_114251.1 & Culture collection & $\begin{array}{l}\text { Nakagawa et al. (2014) } \\
\text { (Unpublished) }\end{array}$ \\
\hline & Lactobacillus spicheri LTH 5753 & $99 \%$ & $97.81 \%$ & NR_025579.1 & Rice sourdough & Meroth et al. (2004) \\
\hline \multirow[t]{5}{*}{ KB1 } & Lactobacillus brevis ATCC 14869 & $99 \%$ & $99.38 \%$ & NR_044704.2 & Culture collection & $\begin{array}{l}\text { Woese et al. (2011) } \\
\text { (Unpublished) }\end{array}$ \\
\hline & $\begin{array}{l}\text { Lactobacillus brevis ATCC } 14869= \\
\text { DSM } 20054\end{array}$ & $97 \%$ & $99.86 \%$ & NR_116238.1 & Dairy product & Coton et al. (2008) \\
\hline & Lactobacillus hammesii TMW 1.1236 & $99 \%$ & $98.15 \%$ & NR_042243.1 & France sourdough & Valcheva et al. (2005) \\
\hline & Lactobacillus senmaizukei DSM 21775 & $99 \%$ & $98.01 \%$ & NR_114251.1 & Culture collection & $\begin{array}{l}\text { Nakagawa et al. (2014) } \\
\text { (Unpublished) }\end{array}$ \\
\hline & $\begin{array}{l}\text { Lactobacillus cerevisiae TUM BP } \\
140423000-2250\end{array}$ & $99 \%$ & $97.80 \%$ & NR_158030.1 & Rice sourdough & Koob et al. (2017) \\
\hline \multirow[t]{5}{*}{$\mathrm{KC} 4$} & Lactobacillus brevis ATCC 14869 & $99 \%$ & $99.45 \%$ & NR_044704.2 & Culture collection & $\begin{array}{l}\text { Woese et al. (2011) } \\
\text { (Unpublished) }\end{array}$ \\
\hline & $\begin{array}{l}\text { Lactobacillus brevis ATCC } 14869= \\
\text { DSM } 20054\end{array}$ & $97 \%$ & $99.93 \%$ & NR_116238.1 & Dairy product & Coton et al. (2008) \\
\hline & Lactobacillus hammesii TMW 1.1236 & $99 \%$ & $98.22 \%$ & NR_042243.1 & France sourdough & Valcheva et al. (2005) \\
\hline & Lactobacillus senmaizukei DSM 21775 & $99 \%$ & $98.09 \%$ & NR_114251.1 & Culture collection & $\begin{array}{l}\text { Nakagawa et al. (2014) } \\
\text { (Unpublished) }\end{array}$ \\
\hline & Lactobacillus spicheri LTH 5753 & $99 \%$ & $97.75 \%$ & NR_025579.1 & Rice sourdough & Meroth et al. (2004) \\
\hline
\end{tabular}

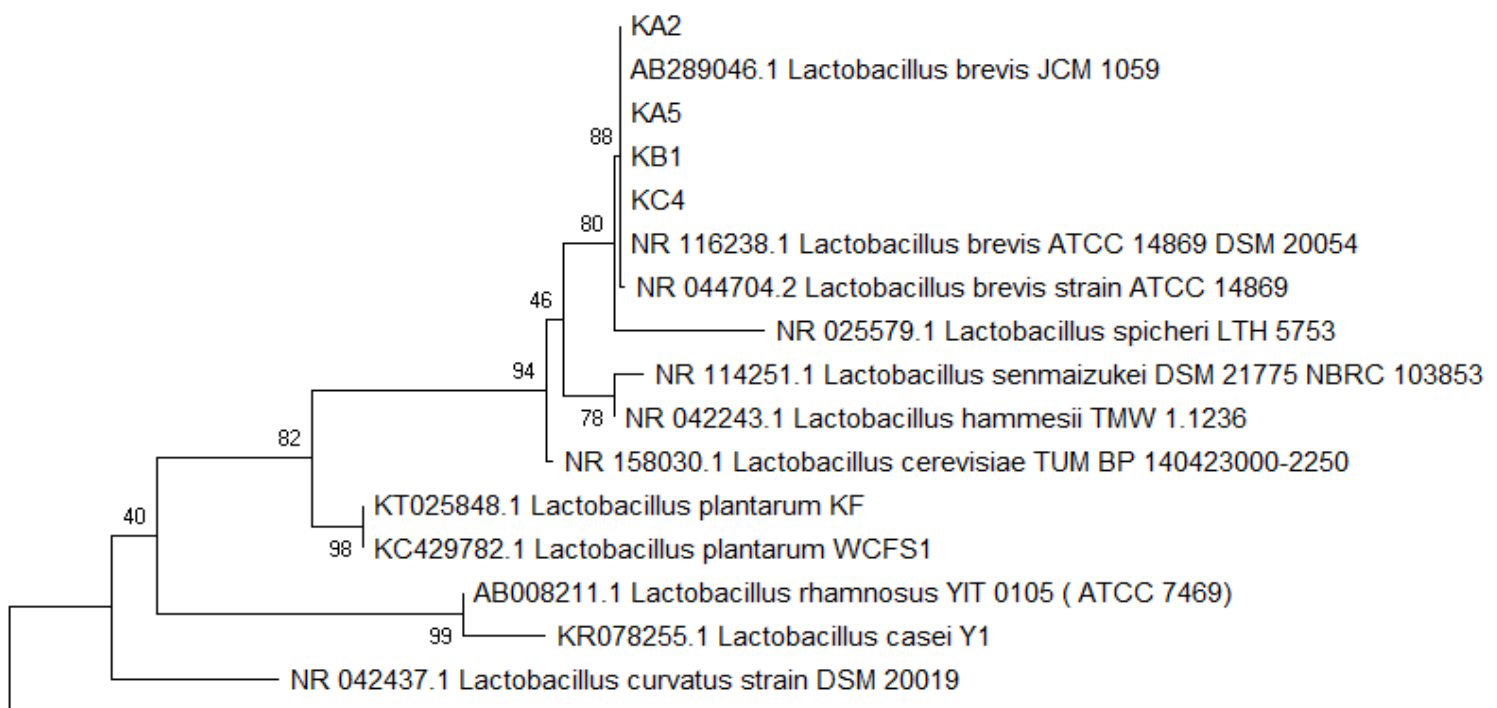

NR 074540.1 Bacillus cereus ATCC 14579

0.050

Figure 4. Phylogenetic tree of LAB isolates from kimchi using the maximum likelihood method (bootstrap: 1000). 
For phylogenetic tree reconstruction, the comparative sequences were used and categorized as an in group and an outgroup. Several comparative sequences of LAB species that produced biofilms were added. These LAB species included Lactobacillus (L.) brevis JCM 1059, L. plantarum KF, L. casei Y1, L. plantarum WCFS1, L rhamnosus YIT 0105 (ATCC 7469), and L. curvatus DSM 20019 (Kubota et al. 2008; Ramirez et al, 2015; Kumar et al. 2017; Song and Lee 2017). Whereas Bacillus cereus ATCC 14579 was used as an out group, because this species separated from the genus Lactobacillus. Bacillus cereus belongs to the order Bacillales, while Lactobacillus is a member of the Lactobacillales order. In addition according to Kwon et al. (2017), this Bacillus cereus produced biofilms.

Further selection of nucleotide substitution models for phylogeny trees important role to determine the interpretation of evolution (Collins et al. 2012). Reconstruction of the phylogenetic tree was based on the maximum likelihood (ML) method with $\mathrm{K} 2+\mathrm{G}$ model (Kimura 2-parameter, G: gamma distribution). This ML principle method was to determine the tree topology, branch length and evolutionary model that maximizes the probability. As explained by Nishimaki and Sato 2019, the Kimura two-parameter (K2P) model was probably the most widely used for estimating genetic differences and phylogenetic relationships in all models of nucleotide substitution. In addition, the $\mathrm{K} 2+\mathrm{G}$ model showed the low AICc (Akaike information criterion) value which represented the best model for phylogenetic reconstruction with ML method. Then it could be checked through MEGA $\mathrm{X}$.

The phylogenetic tree result with bootstrap values which were calculated for 1000 replications (Figure 4). This phylogenetic tree showed a bootstrap value at the inner nodes. The bootstrap values of 88 at the inner nodes explained that the species KA2, L. brevis JCM 1059, KA5, KB1, KC4, L. brevis ATCC 14869 DSM 20054, and L. brevis ATCC 14869 were descendant in $88 \%$ of the bootstrap replications. This phylogenetic tree also represented that four isolates were clustered as Lactobacillus brevis. Thus, they considered as close relatives and indicated as a strain in Lactobacillus brevis species. It proves that BLAST result supports the phylogenetic tree. In conclusion, KA2, KA5, KB1, and KC4 isolate from kimchi produced high biofilms at 48 hours and they were identified as Lactobacillus brevis.

\section{ACKNOWLEDGEMENTS}

This research was supported by INAKOS scholarship. The author would like to thank the entire technicians in Microbiology and Falitma Laboratory for their help to use of laboratory equipment.

\section{REFERENCES}

Bove P, Capozzi V, Garofalo C, Rieuc A, Spano G, Fioccoet D. 2012 Inactivation of the ftsH gene of Lactobacillus plantarum WCFS1:
Effects on growth, stress tolerance, cell surface properties, and biofilm formation. Microbiol Res 167 (4): 187-193.

Brenner DJ, Krieg NR, Staley JR. 2005. Bergey's Manual Systematic Bacteriology. New York, Springer.

Chang J, He X, Bai X, Yuan C. 2020. The impact of hydrodynamic shear force on adhesion morphology and biofilm conformation of Bacillus sp. Ocean Eng 197: 106860

Chen Q, Sa R, Jia J, Xu R. 2017. Research on biofilm formation ability of lactic acid bacteria under different conditions. Adv J Food Sci Technol 13 (2): 77-82.

Collins RA, Boykin LM, Cruickshank RH, Armstrong KF. 2012. Barcoding's next top model: an evaluation of nucleotide substitution models for specimen identification. Methods Ecol Evol 3 (3): 457-465.

Coton M, Berthier F, Coton E. 2008. Rapid identification of the three major species of dairy obligate heterofermenters Lactobacillus brevis, Lactobacillus fermentum and Lactobacillus parabuchneri by speciesspecific duplex PCR. FEMS Microbiol 284 (2): 150-157.

Fan X, McLaughlin C, Ravasini J, Robinson C, George AM. 2018. Zeolite protects mice from iron-induced damage in a mouse model trial. FEBS Open Bio 8 (11):1773-1781.

Fang F, Xu J, Li Q, Xia X, Du G. 2018. Characterization of a Lactobacillus brevis strain with potential oral probiotic properties. BMC Microbiol 18 (221): 1-9.

Gómez NC, Ramiro J MP, Quecan BXV, de Melo Franco BDG. 2016. Use of potential probiotic lactic acid bacteria (LAB) biofilms for the control of Listeria monocytogenes, Salmonella Typhimurium, and Escherichia coli $\mathrm{O} 157: \mathrm{H} 7$ biofilms formation. Front microbiol 7 (863): 1-15.

Guerrieri E, Niederhäusern S, Messi P, Sabia C, Iseppi R, Anacarso I, Bondi M. 2009. Use of lactic acid bacteria (LAB) biofilms for the control of Listeria monocytogenes in a small-scale model. Food Control 20: 861-865.

Hossain MI, Mizan MFR, Ashrafudoulla M, Nahar S, Joo HJ, Jahid IK, Park SH, Kim KS, Ha SD. 2020. Inhibitory effects of probiotic potential lactic acid bacteria isolated from kimchi against Listeria monocytogenes biofilm on lettuce, stainless-steel surfaces, and MBECTM biofilm device. LWT-Food Sci Technol 118: 108864.

Jang JY, Lee ME, Lee HW, Lee JH, Park HW, Choi HJ, Kim TW. 2015. Extending the shelf life of kimchi with Lactococcus lactis strain as a starter culture. Food Sci Biotechnol 24 (3): 1049-1053.

Johnson JS, Spakowicz DJ, Hong B et al. 2019. Evaluation of 16S rRNA gene sequencing for species and strain-level microbiome analysis. Nat Commun 10 (5029): 1-11.

Khatoon Z, McTiernan D, Suuronen EJ, Mah TF, Alarcon EI. 2018. Bacterial biofilm formation on implantable devices and approaches to its treatment and prevention. Heliyon 4 (12): e01067.

Kim M, Chun J. 2014. 16S rRNA gene-based identification of bacteria and archaea using the EzTaxon server. Chapter 4. Elsevier. Methods Microbiol 41: 61-74.

Kim SH, Kim WJ, Kang S. 2019. Inhibitory effect of bacteriocinproducing Lactobacillus brevis DF01 and Pediococcus acidilactici K10 isolated from kimchi on enteropathogenic bacterial adhesion. Food Biosci 30: 100425.

Koob J, Jacob F, Wenning M, Hutzler M. 2017. Lactobacillus cerevisiae sp. nov., isolated from a spoiled brewery sample. Int J Syst Evol Microbiol 67 (9): 3452-3457.

Kubota H, Senda S, Nomura N, Tokuda H, Uchiyama H. 2008. Biofilm formation by lactic acid bacteria and resistance to environmental stress. J Biosci Bioeng 106: 381-386.

Kumar LM, Saad WZ, Mohammad R, Rahim RA. 2017. Influence of biofilm-forming lactic acid bacteria against methicillin-resistant Staphylococcus aureus (MRSA S547). Asian Pac J Trop Biomed 7 (12): 1107-1115.

Kwon M, Hussain MS, Oh DH. 2017. Biofilm formation of Bacillus cereus under food-processing related conditions.Food Sci Biotechnol 26 (4):1103-1111

Lee KW, Shim JM, Park SK, Heo HJ, Kim HJ, Ham KS, and Kim JH. 2016. Isolation of lactic acid bacteria with probiotic potentials from kimchi, traditional Korean fermented vegetable. LWT - Food Sci Technol 71: 130-137.

Meroth CB, Hammes WP, Hertel C. 2004. Characterisation of the microbiota of rice sourdoughs and description of Lactobacillus spicheri sp. nov. Int J Syst Evol Microbiol 27 (2): 151-159. 
Nazir R, Zaffar MR, Amin I. 2019. Bacterial biofilms. Freshw Microbiol 307-340.

Nishimaki T, Sato K. 2019. An Extension of the Kimura two-paramete model to the natural evolutionary process. J Mol Evol 87 (1): 60-67.

Nurhikmayani R, Daryono BS, Retnaningrum E. 2019. Isolation and molecular identification of antimicrobial-producing lactic acid bacteria from chao, South Sulawesi (Indonesia) fermented fish product. Biodiversitas 20 (4): 1063-1068.

Pang X, Yuk H. 2019. Effects of the colonization sequence of Listeria monocytogenes and Pseudomonas fluorescens on survival of biofilm cells under food-related stresses and transfer to salmon. Food Microbiol 82: 142-150.

Piard JC, Briandet R. 2016. Lactic acid bacteria biofilms: from their formation to their health and biotechnological potential. In: Mozzi F, Raya RR, Vignolo GM, Biotechnology of lactic acid bacteria novel applications second edition. Wiley-Blackwell, New York.

Ramírez MDF, Smid EJ, Abee T, Groot MNN. 2015. Characterisation of biofilms formed by Lactobacillus plantarum WCFS1 and food spoilage isolates. Int J Food Microbiol 207: 23-29.

Retnaningrum E, Wilopo W. 2016. Performance and bacterial composition of anodic biofilms in microbial fuel cell using dairy wastewater. AIP Conf Proc 1744 (1): 020018.
Retnaningrum E, Wilopo W. 2017. Removal of sulphate and manganese on synthetic wastewater in sulphate reducing bioreactor using Indonesian natural zeolite. Indones J Chem 17 (2): 203-210.

Schlaberg R, Simmon KE, Fisher MA. 2012. A systematic approach for discovering novel, clinically relevant bacteria. Emerg Infect Dis 18 (3): 422-430.

Seo DJ, Jung D, Jung S, Yeo D, Choi C. 2020. Inhibitory effect of lactic acid bacteria isolated from kimchi against murine norovirus. Food Control 109: 106881

Son SH, Jeon HL, Yang SJ, Lee NK, Paik HD. 2017. In vitro characterization of Lactobacillus brevis KU15006, an isolate from kimchi, reveals anti-adhesion activity against foodborne pathogens and antidiabetic properties. Microb Pathog 112: 135-141.

Song YG, Lee SH. 2017. Inhibitory effects of Lactobacillus rhamnosus and Lactobacillus casei on Candida biofilm of denture surface. Arch Oral Biol. 76: 1-6.

Valcheva R, Korakli M, Onno B, Prevost H, Ivanova I, Ehrmann MA, Dousset X, Ganzle MG, Vogel RF. 2005. Lactobacillus hammesii sp. nov., isolated from French sourdough. Int J Syst Evol Microbiol 55 (2): 763-767.

Valdes A, Ramos M, Beltran A, Jimenez A, Garrigos MC. 2017. State of the art of antimicrobial edible coatings for food packaging applications. Coatings 7 (56): 1-23. 